\title{
Job Satisfaction of Academic Staff Members on Full-Time Appointment in South-Western Nigerian Tertiary Institutions
}

\author{
Omolaiye H. O. ${ }^{1} \quad$ Adeniran A. O. ${ }^{*} \quad$ Olawale A. $\mathrm{O}^{2} . \quad$ Dahunsi T. $\mathrm{N}^{1}$ \\ 1.Department of General Studies, Federal Polytechnic Ile-Oluji, Ondo State, Nigeria \\ 2.Department of Statistics, Federal Polytechnic, Ede, Osun State, Nigeria
}

\begin{abstract}
Man works to earn a living in an organization, and such work can be viewed as an instrument employed to achieve a lot of set personal goals and expectations. This study, therefore, examines job satisfaction of staff members on full-time appointment in South-western Nigerian tertiary institutions. It is a quantitative research in which a wellstructured questionnaire was used to collect responses across eighteen tertiary institutions in South-western Nigeria. A purposive random sampling method was adopted to select a representative sample, and 880 questionnaires were properly selected and analyzed. The validity and reliability tests indicated that the measurement scales met the acceptable standards. Charts were used to present the biographic information of the respondents. The data obtained from the investigation were analyzed using Charts, Correlation Analysis, Regression Analysis and some relevant statistical tools. The findings have revealed a high factor of the academic staff's dissatisfaction with opportunity available for self-development because of poor research environments. Moderate proportion has also revealed staffers' satisfaction with their job. Factors leading to job satisfaction were also revealed. The study, therefore, suggests that Chief Executives of Nigerian tertiary institutions should focus on the identified factors leading to job satisfaction such as good remuneration and welfare package, appreciation and commendation, adequate facilities and teamwork etc. Implementing the aforementioned factors will definitely increase job satisfaction among the academic staff on full-time appointment, thus, reducing the friction rate and creating a stable and reliable teaching/learning environment for academic staff and the students.
\end{abstract}

Keywords Job Satisfaction, Tertiary Institution, Remuneration, Welfare Package, Full-time Appointment, Academic Staff.

DOI: $10.7176 / \mathrm{JEP} / 11-36-10$

Publication date: December $31^{\text {st }} 2020$

\section{Introduction}

Human works to earn a living either in an organization or an institution. Such work can be viewed as a means to achieve a lot of set personal goals. When a job meets or exceeds an individual's expectation, the individual often experiences positive emotions and these positive emotions represent job satisfaction. Job satisfaction provides an employee with a reason to continue with the job he engages in. It is the relationship between what everyone expects in accordance to what everyone achieves. In essence, job satisfaction could be viewed either from the physical or psychological perspective. This is why scholars' definitions seem not to encapsulate the concept of job satisfaction because of its complexity and elusiveness in nature. For instance, (Veitch, Charles, Farley \& Newsham, 2007) view job satisfaction from two perspectives: that is, the feelings of the employees in line with "favourable" and "unfavourable" attachments towards their job. In their own view, (Gurinder \& Gursharan, 2010) define job satisfaction as "the positive emotional response to the job situation resulting from attaining what the employee wants from the job". In the same manner, (Nguni, Sleegers \& Denessen, 2006) describe job satisfaction as a magnificent or positive emotional state resulting from the appraisal of one's job or job experiences and as achieving or facilitating the achievement of one's job values. The definitions above have revealed the concept of job satisfaction as being subjective and intricate. However, the definitions have brought one thing to the fore-achieving the set goals of one's job.

In early 1940's, motivation in the field of Employee Satisfaction has explained the importance of fulfilling the needs of employee to achieve a productive and satisfied workforce (Maslow, 1943) and (Herzberg \& Mausner, 1959). (Lincoln \& Kalleberg, 1990) submit that job satisfaction of staff is the generalized perception of an employee's job success. However, (Allen 2001) and (Blackwell \& Bryson, 2006) have emphasized the hamper effect that full-time employment conditions may have on the job satisfaction of staff.

As noted, tertiary institutions are vital tools used to booster innovation and performances in the field of Science and Technology, as well as Arts and Humanities. They are the vehicle used in promoting economic growth of a nation. Providing quality education via teaching and learning, thus, becomes indispensable tools in the hand of academic staff in tertiary institutions. In other words, lecturers, particularly are seen as the driving force in achieving the economic growth of a nation. However, this might not be achievable if the academic staff experience low level of job satisfaction. In view of this, this research, therefore, tends to investigate the level of job satisfaction, identify factors responsible for job satisfaction and examine the needs and challenges of job satisfaction. The study will also beam its searchlight on biographic information of the respondents, means of job parameter score and do 
a descriptive summary of demographic profile. By so doing, the researchers would provide possible strategies that could lead to the improving of the level of job satisfaction that might be experienced by full-time appointment of academic staff members.

The rationale behind this research, therefore, is based on the fact that researches pertaining to level of job satisfaction among full-time academic staff were rather limited. More importantly, academic staffers of tertiary institutions in South-Western Nigeria, with respect to job satisfaction, do not receive much empirical investigation, hence leaving a gap to be filled by this present research.

Justifying the identified gap, (Howell and Hoyt, 2007) have identified underlying uncertainties and frustrations among full-time academic staff members, and the challenge of keeping those staffers committed to their primary assignment (Bryson and Barnes, 2000).

Subsequently, the problems associated with full-time appointments that usually give rise to research questions like: How can the Job Satisfaction of full-time academic staffers in tertiary educational institutions in Nigeria, with regard to academic engagement and success, can be addressed? What are the levels of job satisfaction of academic staff of full-time employment? How does job satisfaction relate to Human Resource Management? How can job satisfaction of full-time academic staffers in Nigerian tertiary institutions be sustained? This research is, therefore, out to respond to the fundamental issues raised.

\section{Literature Review}

Literature reveals a lot of existing work on job satisfaction among employees of various institutions. However, a systematic review of studies on Job Satisfaction among academic staff of previous researches has been reported in the table below:

Table 1: Review of relevant literature on job satisfaction among academic staff

\begin{tabular}{|c|c|c|c|c|c|}
\hline No. & $\begin{array}{l}\text { Author(s) and } \\
\text { year }\end{array}$ & Population & Methodology & Areas of Focus & Findings \\
\hline 1. & $\begin{array}{l}\text { (Ssesanga \& } \\
\text { Garrett 2005) }\end{array}$ & $\begin{array}{l}\text { University } \\
\text { Lecturers in } \\
\text { Uganda. } \\
(\mathrm{N}=182) \\
\text { Note: Categories of } \\
\text { lecturers not } \\
\text { specified }\end{array}$ & $\begin{array}{l}\text { Empirical } \\
\text { investigation }\end{array}$ & $\begin{array}{l}\text { Remuneration, } \\
\text { promotion, } \\
\text { research impact, } \\
\text { governance and } \\
\text { working } \\
\text { environment } \\
\text { Coupled } \\
\text { demographic } \\
\text { factors like age, } \\
\text { rank, and tenure } \\
\text { on job satisfaction }\end{array}$ & $\begin{array}{l}\text { Age, Tenure and Position } \\
\text { determine academic job } \\
\text { satisfaction while gender } \\
\text { is insignificant on job } \\
\text { satisfaction. }\end{array}$ \\
\hline 2. & $\begin{array}{l}\text { (Santhapparaj\& } \\
\text { Alam 2005) }\end{array}$ & $\begin{array}{l}\text { Academic staff in } \\
\text { private universities } \\
\text { in Malaysia. }(\mathrm{N}= \\
\text { 173) }\end{array}$ & $\begin{array}{l}\text { Empirical } \\
\text { investigation }\end{array}$ & $\begin{array}{l}\text { Level of } \\
\text { remuneration, } \\
\text { fringe benefits, } \\
\text { promotion, } \\
\text { research impact, } \\
\text { working } \\
\text { condition, support } \\
\text { of teaching on job } \\
\text { satisfaction }\end{array}$ & $\begin{array}{l}\text { Promotion as and well } \\
\text { due, good remuneration, } \\
\text { support of research and } \\
\text { working condition have } \\
\text { positive effect on job } \\
\text { satisfaction while } \\
\text { support of teaching and } \\
\text { fringe benefits have } \\
\text { negative effect on job } \\
\text { satisfaction }\end{array}$ \\
\hline 3. & $\begin{array}{l}\text { (Abdullah et. al } \\
\text { 2009) }\end{array}$ & $\begin{array}{l}\text { Academic staff of } \\
\text { King Faisal } \\
\text { University - } \\
\text { Dammam (KFU- } \\
\text { D). }(\mathrm{N}=248)\end{array}$ & $\begin{array}{l}\text { Empirical } \\
\text { investigation }\end{array}$ & $\begin{array}{l}\text { Levels of job } \\
\text { satisfaction }\end{array}$ & $\begin{array}{l}\text { Good supervision, taking } \\
\text { responsibility, and } \\
\text { interpersonal } \\
\text { relationships have } \\
\text { positive effect on job } \\
\text { satisfaction. }\end{array}$ \\
\hline 4. & (Saba 2011) & $\begin{array}{l}\text { Academic Staff in } \\
\text { Bahawalpur } \\
\text { Colleges }(N=108)\end{array}$ & $\begin{array}{l}\text { Empirical } \\
\text { investigation }\end{array}$ & $\begin{array}{l}\text { work, pay, } \\
\text { promotion } \\
\text { opportunities, } \\
\text { working } \\
\text { conditions, job } \\
\text { security and } \\
\text { coworkers. }\end{array}$ & $\begin{array}{l}\text { work, pay, working } \\
\text { conditions, job security } \\
\text { and } \\
\text { coworkers }\end{array}$ \\
\hline
\end{tabular}




\begin{tabular}{|c|c|c|c|c|c|}
\hline No. & $\begin{array}{l}\text { Author(s) and } \\
\text { year }\end{array}$ & Population & Methodology & Areas of Focus & Findings \\
\hline 5 & (James 2011) & $\begin{array}{l}\text { Staff of Nigeria } \\
\text { Breweries, Ama, } \\
\text { Enugu State, } \\
\text { Nigeria }(\mathrm{N}=250)\end{array}$ & $\begin{array}{l}\text { Empirical } \\
\text { investigation }\end{array}$ & $\begin{array}{l}\text { Relation between } \\
\text { supports from } \\
\text { colleagues and job } \\
\text { satisfaction }\end{array}$ & $\begin{array}{l}\text { Supports from colleagues } \\
\text { have positive effect on } \\
\text { job satisfaction }\end{array}$ \\
\hline 6 & $\begin{array}{l}\text { (Malik et. al } \\
\text { 2012) }\end{array}$ & $\begin{array}{l}\text { Educational staff in } \\
\text { public and private } \\
\text { universities in } \\
\text { Punjab, Pakistan. } \\
(\mathrm{N}=200)\end{array}$ & $\begin{array}{l}\text { Empirical } \\
\text { investigation }\end{array}$ & $\begin{array}{l}\text { Impact of good } \\
\text { remuneration and } \\
\text { promotion on job } \\
\text { satisfaction }\end{array}$ & $\begin{array}{l}\text { Good remuneration and } \\
\text { promotion have positive } \\
\text { effect on job satisfaction. } \\
\text { However, good } \\
\text { remuneration has more } \\
\text { positive effects on job } \\
\text { satisfaction than } \\
\text { promotion }\end{array}$ \\
\hline 7 & $\begin{array}{l}\text { (Derakhshani } \\
\text { Ghasemzadeh } \\
\text { et. al 2014) }\end{array}$ & $\begin{array}{l}\text { Faculty members } \\
\text { of East Azerbaijan } \\
\text { PNU, Iran. }(\mathrm{N}= \\
55)\end{array}$ & $\begin{array}{l}\text { Empirical } \\
\text { investigation }\end{array}$ & $\begin{array}{l}\text { Correlation } \\
\text { between } \\
\text { Accountability, } \\
\text { Job Satisfaction, } \\
\text { Job Performance, } \\
\text { Job Tension and } \\
\text { Organizational } \\
\text { Citizenship } \\
\text { Behaviour (OCB) }\end{array}$ & $\begin{array}{l}\text { Accountability has } \\
\text { positive effect on job } \\
\text { satisfaction while others } \\
\text { have comparatively less } \\
\text { effect on job satisfaction. }\end{array}$ \\
\hline 8. & $\begin{array}{l}\text { (Akafo \& } \\
\text { Boateng, 2015) }\end{array}$ & $\begin{array}{l}\text { Academic staff of } \\
\text { private universities } \\
\text { (7) in Nigeria. }(\mathrm{N}= \\
\text { 157) }\end{array}$ & $\begin{array}{l}\text { Empirical } \\
\text { investigation }\end{array}$ & $\begin{array}{l}\text { Impact of rewards } \\
\text { and recognition } \\
\text { on job satisfaction } \\
\text { among academic } \\
\text { staff }\end{array}$ & $\begin{array}{l}\text { Positive relation between } \\
\text { rewards and job } \\
\text { satisfaction enhance } \\
\text { productivity. }\end{array}$ \\
\hline 9 & $\begin{array}{l}\text { Amarasena, et. } \\
\text { al. } \\
(2015)\end{array}$ & $\begin{array}{l}\text { Academic Staff of } \\
\text { Government } \\
\text { Universities in } \\
\text { Sri Lanka(N= } \\
\text { 423) }\end{array}$ & $\begin{array}{l}\text { Empirical } \\
\text { investigation }\end{array}$ & $\begin{array}{l}\text { Work Load and } \\
\text { Working } \\
\text { Environment }\end{array}$ & $\begin{array}{l}\text { Work autonomy has } \\
\text { great impact on job } \\
\text { satisfaction. }\end{array}$ \\
\hline 10 & (Barlas 2016) & $\begin{array}{l}\text { Academic } \\
\text { staff in a } \\
\text { faculty of } \\
\text { Turkish } \\
\text { university } \\
(\mathrm{N}=74)\end{array}$ & $\begin{array}{l}\text { Empirical } \\
\text { investigation }\end{array}$ & $\begin{array}{l}\text { Tenural Position, } \\
\text { Tenure, Age, } \\
\text { Gender, } \\
\text { Compensation } \\
\text { and marital status }\end{array}$ & $\begin{array}{l}\text { Job type and job level } \\
\text { significant have impact } \\
\text { on job satisfaction. }\end{array}$ \\
\hline 11 & $\begin{array}{l}\text { (Asan \& } \\
\text { Wirba, 2017) }\end{array}$ & $\begin{array}{l}\text { Academic staff } \\
\text { from different } \\
\text { institutions in the } \\
\text { Eastern Province of } \\
\text { Saudi Arabia. (N = } \\
\text { 30) }\end{array}$ & $\begin{array}{l}\text { Empirical } \\
\text { investigation }\end{array}$ & $\begin{array}{l}\text { Good } \\
\text { remuneration, } \\
\text { promotion, } \\
\text { supervision, } \\
\text { fringe benefits, } \\
\text { contingent } \\
\text { rewards, } \\
\text { operational } \\
\text { conditions, co- } \\
\text { workers, nature of } \\
\text { work, and } \\
\text { communication } \\
\text { on job satisfaction }\end{array}$ & $\begin{array}{l}\text { Good pay, promotion, } \\
\text { supervision, } \\
\text { fringe benefits, } \\
\text { contingent rewards have } \\
\text { positive effect on job } \\
\text { satisfaction. However, } \\
\text { others are less } \\
\text { significant. }\end{array}$ \\
\hline
\end{tabular}




\begin{tabular}{|l|l|l|l|l|l|}
\hline No. & $\begin{array}{l}\text { Author(s) and } \\
\text { year }\end{array}$ & Population & Methodology & Areas of Focus & Findings \\
\hline 12 & $\begin{array}{l}\text { Adnan jawabri } \\
2017)\end{array}$ & $\begin{array}{l}\text { Academic Staff of } \\
\text { Higher Education } \\
\text { of Private } \\
\text { Universities in } \\
\text { UAE(N=212) }\end{array}$ & $\begin{array}{l}\text { Empirical } \\
\text { investigation }\end{array}$ & $\begin{array}{l}\text { Working hours, } \\
\text { Promotion, } \\
\text { Job } \\
\text { Responsibilities, } \\
\text { Recognition and } \\
\text { rewards done, } \\
\text { Supervisor } \\
\text { Support, } \\
\text { Salary, } \\
\text { Colleagues } \\
\text { Support. }\end{array}$ & $\begin{array}{l}\text { Support from supervisor, } \\
\text { chance of promotion and } \\
\text { support from } \\
\text { job satisfaction in the } \\
\text { academic staff of private } \\
\text { universities in UAE. }\end{array}$ \\
\hline 13 & $\begin{array}{l}\text { (Moloantoa \& } \\
\text { Dorasamy } \\
2017)\end{array}$ & $\begin{array}{l}\text { academic } \\
\text { employees in } \\
\text { institutions of } \\
\text { higher } \\
\text { learning in South } \\
\text { Africa }\end{array}$ & investigation & $\begin{array}{l}\text { Benefits, } \\
\text { Allowances, Lack } \\
\text { of Equipment, as } \\
\text { well as Poor } \\
\text { Institutional } \\
\text { Management. }\end{array}$ & $\begin{array}{l}\text { Prompt payment of } \\
\text { salary has great impact } \\
\text { on job satisfaction. }\end{array}$ \\
\hline
\end{tabular}

A lot of research has been carried out in the field of job satisfaction but not much on factors responsible for job satisfaction in the academic sector in Nigeria, particularly, higher Institutions. Furthermore, several studies on job satisfaction in education sector have been conducted in various geographical areas across the world, however, literature on job satisfaction in south western Nigeria higher institutions are scanty, hence leaving a gap to fill in the study.

\subsection{Research Methodology}

The success of a research work depends largely on the methodological framework adopted. The methodology used for this study has been designed to enhance the realization of the researchers' goal in the work. It takes care of population, reliability of the instrument for data collection, method of data collection etc. These are briefly discussed below.

\subsection{Sample}

The target population for the present study includes some randomly selected academic staff members on full-time appointment in South-western Nigerian Tertiary institution. The tertiary institutions are Colleges of Education, Polytechnics, and Universities. Eighteen tertiary institutions were randomly selected in which case, three tertiary institutions per state were selected from Colleges of Education, Polytechnics, and Universities. The empirical investigation was conducted on 880 academic staff members. The sample respondents were selected through Random Probability sampling technique, where each staff member of the target population had the same probability of being chosen as the sample of the study.

\subsection{Questionnaire Design}

A 5-point Likert scale questionnaire was constructed based on six sections which are used as parameters to determine job satisfaction. This questionnaire also consisted of sections on biographic information and general background on Job satisfaction in the selected tertiary institutions in South-western Nigeria. The reliability of this questionnaire was assessed by conducting the Cronbach alpha reliability test.

Table 2: Reliability Test

\begin{tabular}{ll}
\hline Cronbach's Alpha & No. of Items \\
\hline 0.925 & 83 \\
\hline
\end{tabular}

Since the value is higher than the minimum required value of 0.6 , it was asserted that the questionnaire used is reliable. Hence, further analysis could be conducted.

\subsection{Data Analysis Procedure}

The collected responses from the respondents were coded in MS Excel and transferred to SPSS v16.0. Descriptive Statistics was performed on the biographic profile and general background responses. As regards testing the hypothesis, Correlation and Regression tests were performed on the Likert scale questions. The casual relationship between the dependent and independent variables was studied to determine the most influential factors leading to job satisfaction among the academic staff members on full-time appointment. 


\subsection{Data Analysis}

4.1 Biographic information

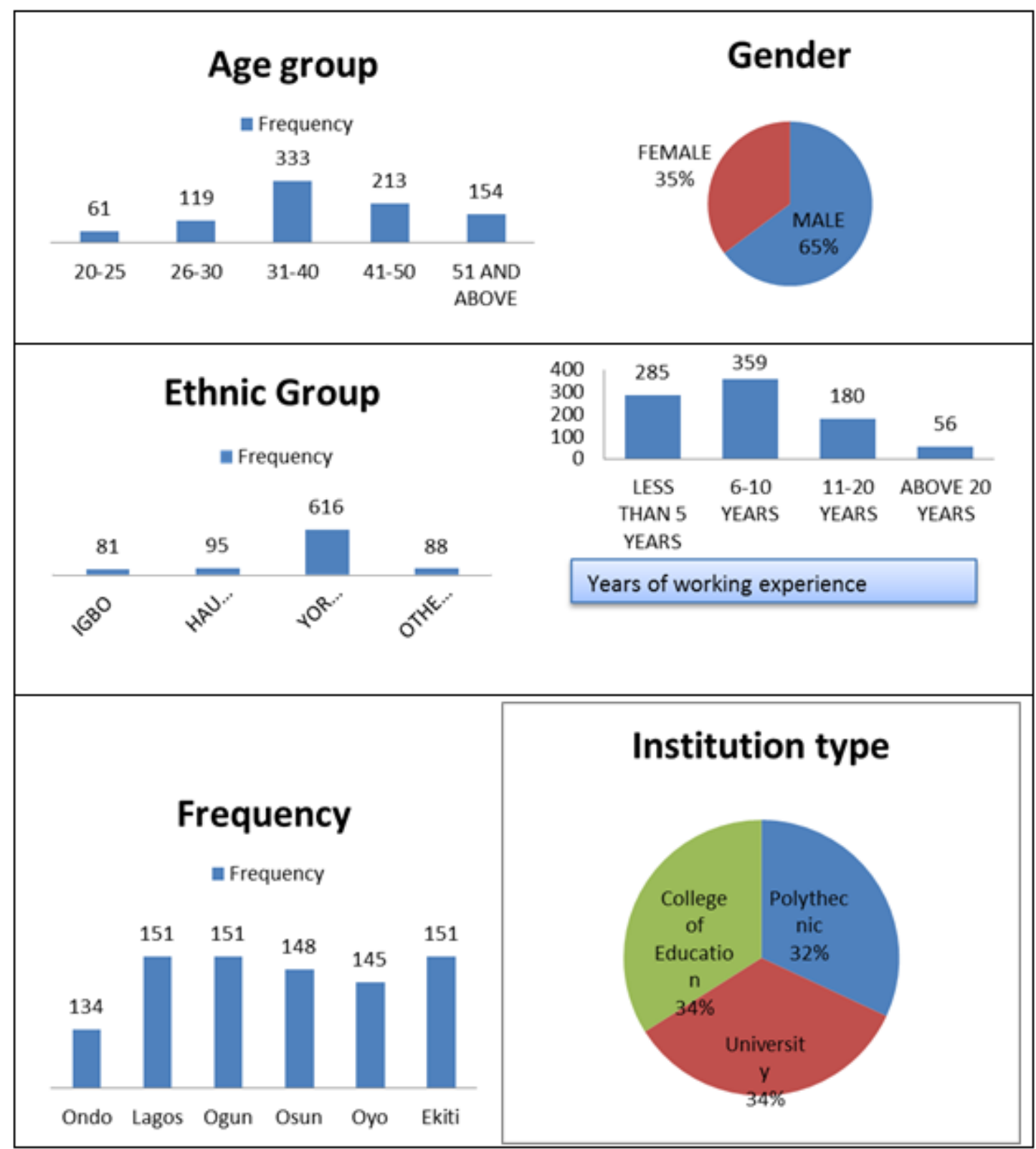

Figure 1.Biographic information of the respondents. 
Table 3. Descriptive Summary of Demographic Profile

\begin{tabular}{|c|c|c|c|c|}
\hline Characteristics & Frequency & Percentage & Mean & Standard deviation \\
\hline \multicolumn{5}{|l|}{ Gender } \\
\hline Male & 570 & 64.8 & \multirow[t]{2}{*}{1.35} & \multirow[t]{2}{*}{0.478} \\
\hline Female & 310 & 35.2 & & \\
\hline \multicolumn{3}{|l|}{ Age } & \multirow{6}{*}{3.32} & \multirow{6}{*}{1.12} \\
\hline $20-25$ & 61 & 6.9 & & \\
\hline $26-30$ & 119 & 13.5 & & \\
\hline $31-40$ & 333 & 37.8 & & \\
\hline $41-50$ & 213 & 24.2 & & \\
\hline 51 and above & 154 & 17.5 & & \\
\hline \multicolumn{3}{|l|}{ Ethnic group } & \multirow{5}{*}{2.81} & \multirow{5}{*}{0.735} \\
\hline Igbo & 81 & 9.2 & & \\
\hline Hausa/Fulani & 95 & 10.8 & & \\
\hline Yoruba & 616 & 70.0 & & \\
\hline Others & 88 & 10.0 & & \\
\hline \multicolumn{3}{|c|}{ Years of working experience } & \multirow[b]{5}{*}{2.01} & \multirow[b]{5}{*}{0.885} \\
\hline Less than 5 years & 285 & 32.4 & & \\
\hline $6-10$ years & 359 & 40.8 & & \\
\hline $11-20$ years & 180 & 20.5 & & \\
\hline Above 20 years & 56 & 6.4 & & \\
\hline \multicolumn{3}{|l|}{ Institution } & \multirow{4}{*}{2.02} & \multirow{4}{*}{0.812} \\
\hline Polytechnic & 281 & 31.9 & & \\
\hline University & 300 & 34.1 & & \\
\hline College of education & 299 & 34.0 & & \\
\hline \multicolumn{3}{|l|}{ State of origin } & \multirow{7}{*}{3.54} & \multirow{7}{*}{1.693} \\
\hline Ondo & 134 & 15.2 & & \\
\hline Lagos & 151 & 17.2 & & \\
\hline Ogun & 151 & 17.2 & & \\
\hline Osun & 148 & 16.8 & & \\
\hline Oyo & 145 & 16.5 & & \\
\hline Ekiti & 151 & 17.2 & & \\
\hline
\end{tabular}

\subsection{General Background}

4.2.1 Level of Job Satisfaction

Chart 2: showing Level of Job Satisfaction among the Academic Staff surveyed

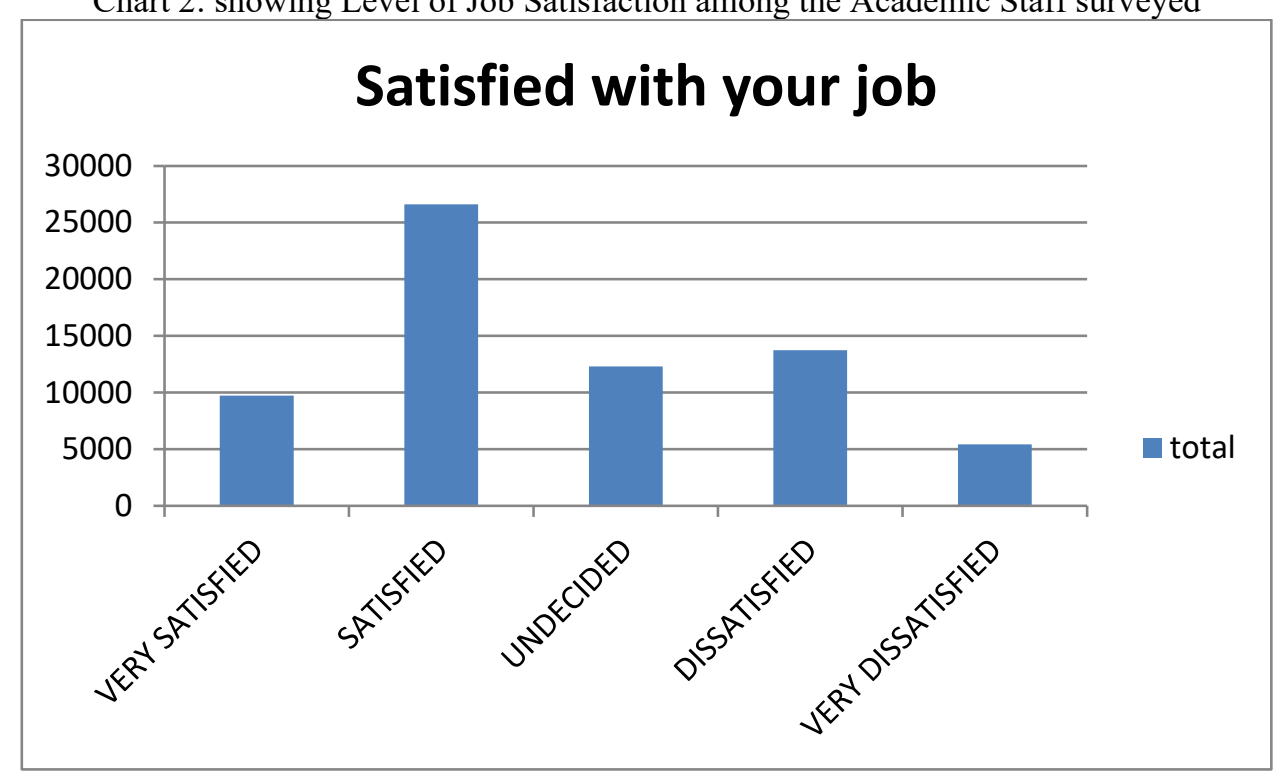

From the figure above, it could be inferred that the Academic staffers who are satisfied are the highest frequency while those that are very dissatisfied are least. 
4.2.2 Level of Job Satisfaction with Respect to Institution Type

Chart 3: showing Level of Job Satisfaction with Respect to Institution Type

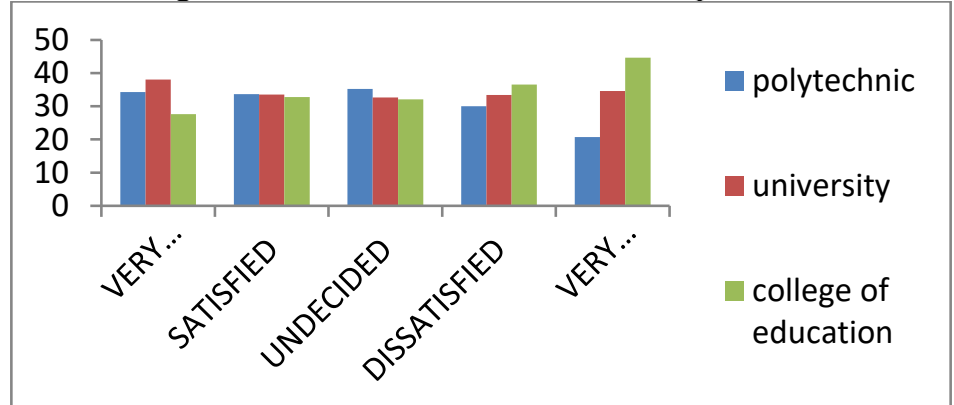

From the figure above, it could also be inferred that Academic Staff of University have the highest frequency while Academic Staff of Colleges of Education have the least frequency in the Very Satisfied Response. In the case of Satisfied Response, Academic Staff of Polytechnics have the highest frequency while Academic Staff of Colleges of Education have the least frequency of Colleges of Education.

Academic Staff of Colleges of Education have the highest frequency while Academic Staff of Polytechnics have the least frequency in the Dissatisfied Response.

Academic Staff of Colleges of Education have the highest frequency while Academic Staff of Polytechnics have the least frequency in Very Dissatisfied Response.

Table 4: Mean of Job Satisfaction Parameter Scores on Basis of Gender of Respondents

\begin{tabular}{|c|c|c|c|c|}
\hline \multicolumn{5}{|c|}{ FAVOUR ITEM } \\
\hline & ITEM SCORE & MALE (\%) & FEMALE $(\%)$ & TOTAL $(\%)$ \\
\hline Self-Development & 2.275325 & 69.7995 & 67.58875 & 68.69413 \\
\hline Remuneration and Welfare Package & 2.966818 & 42.86550 & 42.66667 & 42.76609 \\
\hline Appreciation/Commendation & 3.553864 & 20.59649 & 13.57895 & 17.08772 \\
\hline Facilities & 2.496329 & 60.63158 & 59.85802 & 60.24480 \\
\hline Teamwork & 2.617436 & 53.84897 & 29.62936 & 41.73917 \\
\hline HOD Leadership Style & 2.548201 & 63.12865 & 32.19298 & 47.66082 \\
\hline
\end{tabular}

The table above depicts the average item scores given by respondents for agreement on job satisfaction on the basis of several parameters. It could therefore, be interpreted that the respondents agree maximum with the item on self-development i.e. there is room for the academic staff to develop and sustain themselves as these have impact on job satisfaction. This could be that their level of growth and development will determine their first promotion and increased pay. Similarly, the value of item score for (Appreciation/Commendation) is maximum when compared to other items i.e. the item does not hold importance when it comes to the job satisfactory level of the academic staff.

Table 5. Satisfaction On The Basis Of Demographic Factors- Gender, Age and Designation

\begin{tabular}{|c|c|c|}
\hline Demographic Profile & Variable & Satisfaction \\
\hline \multirow[b]{2}{*}{ Gender } & MALE & 53.10439 \\
\hline & FEMALE & 52.15042 \\
\hline \multirow{5}{*}{ Age } & $20-25$ & 60.10363 \\
\hline & $26-30$ & 56.65501 \\
\hline & $31-40$ & 51.34295 \\
\hline & $41-50$ & 52.3648 \\
\hline & 51 AND ABOVE & 52.25363 \\
\hline \multirow{4}{*}{ Years of Work experience } & Less than 5 years & 59.90766 \\
\hline & $6-10$ years & 55.84138 \\
\hline & $11-20$ years & 52.28652 \\
\hline & Above 20 years & 46.34378 \\
\hline \multirow[t]{2}{*}{ Primary Source of Income } & Yes & 54.61955 \\
\hline & No & 61.51238 \\
\hline \multirow{3}{*}{ Institutions Type } & Polytechnic & 44.14403 \\
\hline & University & 41.56899 \\
\hline & College of Education & 34.77560 \\
\hline
\end{tabular}

It can be seen that more number of Male staff are satisfied than Female staff which is in conformity to the findings of Hesli \& Lee, (2013). However, this is contrary to the work of Adnan \& Jawabri (2017). In view of this, it could be conveniently stated that gender does not play a role when it comes to job satisfaction among academic 
staff. Age 20-25 is more satisfied than other age range, being that they are new in the system and may not have been given many responsibilities. The years of work experience of less than 5 years are more satisfied than other higher years, reason being that no much responsibility given to them. The academic staff of Colleges of Education are least satisfied as this is evident in our findings.

\subsection{Inferential Analysis}

Table 6 : Tolerance level and VIF Factors of Job Satisfaction parameters

\begin{tabular}{lll}
\hline VARIABLE & Tolerance & VIF \\
\hline RWP & 1.000 & 1.000 \\
\hline A/C & 0.384 & 2.603 \\
\hline (T) & .0750 & 13.339 \\
\hline (F) & .0450 & 22.440 \\
\hline
\end{tabular}

Table 7: Correlation Results for Factors Leading To Job Satisfaction

\begin{tabular}{llllllll}
\hline & & $(\mathrm{SD})$ & $(\mathrm{RWP})$ & $\mathrm{A} / \mathrm{C}$ & $(\mathrm{F})$ & $(\mathrm{T})$ & $(\mathrm{HLS})$ \\
\hline (SD) & Correlation Coefficient & 1.000 & & & & & \\
\hline (RWP) & Correlation Coefficient & .300 & 1.000 & & & & \\
\hline$(\mathrm{A} / \mathrm{C})$ & Correlation Coefficient & -.800 & .300 & 1.000 & & & \\
\hline (F) & Correlation Coefficient & $.900^{*}$ & .400 & -.600 & 1.000 & & \\
\hline (T) & Correlation Coefficient & .700 & .800 & -.200 & .600 & 1.000 & \\
\hline (HLS) & Correlation Coefficient & .700 & .700 & -.200 & $.900^{*}$ & .700 & 1.000 \\
\hline
\end{tabular}

Notes: *Significant level at $\mathrm{P} \leq 0.05$ (two tailed):Self- Development(SD) ;Remuneration and Welfare Package(RWP); Appreciation/Commendation (A/C); Facilities (F); Teamwork (T); HOD Leadership Style (HLS).

The result of the correlation analysis as presented in the table above depicts that a greater number of factors are statistically significant as this shows positive relationship under used measure $(\mathrm{P} \leq 0.05)$.

The level of self-development (SD) with the facility used (0.900) has a high significant positive correlation on the level of job satisfaction of the academic staff (i.e the better the facility the better the level of selfdevelopment), which has a high equal positive relational significance with the teamwork (T) and head of department leadership style (HLSD) respectively, on job satisfaction.

The remunerations and welfare package (RWP) has high positive correlation with team work level $(0.800)$ and head of development (0.700). That is, the RWP, in form of salary and other incentives, play a vital role in encouraging and strengthening team work, and the leadership style of the various Heads of Department jointly affecting job satisfaction level. This will jointly affect job facility and team work (0.600). The table above reveals the moderate effect which improving facility can have on the team level of commitment to work, thereby strengthening efficiency, productivity and flexibility of the job at hand.

Standard Regression Equation:

$Y=a+b_{1} X_{1}+b_{2} X_{2}+b_{3} X_{3}+b_{4} X_{4}+b_{5} X_{5}+b_{6} X_{6}$

Where:

$Y=$ Dependent variable (Job Satisfaction)

$X_{1}, X_{2}, X_{3}, X_{4}, X_{5}, X_{6}$ are independent factors (6 grouping factors were taken into the study to be responsible for job satisfaction)

$\mathrm{a}=$ intercept

$\mathrm{b}=$ slope

Table 8: Summary of Model, ANOVA and Regression coefficients for Regression of Factors Leading to Job Satisfaction (factor against antecedent factor Institution type)

\begin{tabular}{|c|c|c|c|c|c|c|}
\hline Model & $\begin{array}{l}\text { Standardized co-efficient } \\
\text { (Beta) }\end{array}$ & $t$ & sig & $R^{2}$ & $\mathrm{~F}$ & Model Significance \\
\hline (Constant) & & 9.711 & .000 & \multirow[t]{7}{*}{0.473} & \multirow[t]{7}{*}{9.324} & \multirow[t]{7}{*}{.000} \\
\hline (SD) & -0.02834 & -0.93281 & 0.304939 & & & \\
\hline (RWP) & 0.020498 & 0.498932 & 0.236869 & & & \\
\hline$(\mathrm{A} / \mathrm{C})$ & 0.029022 & 0.647823 & 0.567255 & & & \\
\hline$(\mathrm{F})$ & 0.023555 & 0.402955 & 0.217662 & & & \\
\hline (T) & 0.00319 & 0.068016 & 0.432504 & & & \\
\hline (HLS) & -0.00845 & -0.18064 & 0.381542 & & & \\
\hline
\end{tabular}

From the table above, the regression model shows a significant $R^{2}$ value $(0.473)$ which implies that $47.3 \%$ of the variation in the dependent variable was a direct result of the independent variables (antecedents of job satisfaction). Also, considering the ANOVA results, the F-value of 9.324 and a high significance of this model at 
$\mathrm{p}=.000$, confirms that the null hypothesis can be rejected and the alternate hypothesis can be accepted. Regression coefficient analysis in the table above was carried out to determine the significance of the predicted variable and how the independent variables (6 parameters) influence overall job satisfaction of academic staff. From the table, it can be seen that only few variables significantly influence job satisfaction among the academic staff.

When evaluation of the standard coefficients was done, it was found that; "appreciation and commendation" (.029) showed the highest influence towards job satisfaction in academic staff owing to its high Standardized coefficient values. This suggest that appreciation and commendation received from other colleagues and school management is one of the factors that mostly contribute to increase in job satisfaction among academic staff members on full-time appointment in South-Western Nigeria. Also, "facilities" ( $p=0.024)$ was seen to be positively affecting job satisfaction. Thus, as the quality of facilities improves, job satisfaction of the academic staff also increases. Furthermore, "remuneration and welfare package" $(\mathrm{p}=0.020)$ also enhances job satisfaction. It is noted that bad leadership (Head of Department's leadership style) and bad self-development could affect job satisfaction negatively.

\section{Conclusion}

The essence of this study is to determine the level of job satisfaction among the academic staff members on fulltime appointment in South-Western Nigeria. Based on findings, moderate proportion of the sampled academic staff is satisfied with their job while a very small part of the sample is not satisfied with the job engage in. This has revealed the fact that teaching and learning environment is moderately conducive

The correlation analysis has revealed a high fraction of the academic staff that is dissatisfied with the opportunity available for self-development. Also, appreciation and commendation received from management are not commendable as evident in correlation table, where the correlation co-efficient is highly negative.

Further, the study has attempted to investigate the factors leading to job satisfaction. It has been discovered that Good Remuneration and Welfare Package, Appreciation and Commendation, Adequate Facilities and Teamwork boost job satisfaction. A good remuneration and welfare package such as annual increment as and when due, level and step placement, Incentives for extra job done and commensuration of monthly salary with job done will increase and lead to job satisfaction among academic staff.

Appreciating and commending staff members in the areas of 'accelerated promotion', annual award for productivity among others will also have positive effect on job satisfaction. Functional and adequate facilities will boost lecture delivery, thus, enhancing job satisfaction.

The findings of the present study, if adopted by chief executives of Nigerian tertiary institutions, will definitely increase job satisfaction among the academic staff, thus, reducing the friction rate and creating a stable and reliable learning environment for students which will in turn be beneficial to the growth and development of tertiary institutions in Nigeria. It must be added that the study has revealed the academic staff' dissatisfaction with their level of self-development because of in conducive environment. Thus, conducive environment should be provided to enhance increase in productivity. As regards Head of Departments' leadership styles, it will be proper for the management to organize regular leadership trainings so as to boost their leadership skills. Also, there is need for the management to emphasize on the advantage of the teamwork as teamwork enhances work efficiency and increase in productivity.

\section{Acknowledgement}

Researchers of this present study acknowledge and sincerely appreciate the academic developer, (Tertiary Education Trust Fund (TETFund, Nigeria) for sponsoring this research via its Institution Based Research (IBR) Intervention. The researchers also acknowledge and appreciate the Management of the Federal Polytechnic, IleOluji, Ondo State for its support. The management's efforts have created the enabling environment which culminated in the success of this research.

\section{References}

Abdullah, M. A., Sheikh, I. A.R., Mahdi,S, A., \& Wosornu, L. (2009). Job Satisfaction among the Academic Staff of a Saudi University: An Evaluative Study. Journal of Family \& Community Medicine, 16(3), 97-103.

Adnan, J. (2017), Job Satisfaction of Academic Staff in the Higher Education:Evidence from Private Universities in UAE. International Journal of Human Resource Studies, Vol. 7, No. 4.

Akafo, V., \& Boateng, P. A. (2015). Impact of Reward and Recognition on Job Satisfaction and Motivation. European Journal of Business and Management, 7(2).

Allen, L. (2001). In from cold? Part-time Teaching, Professional Development and the ILT, ULF/NAFTHE (and others), London.

Amarasena, T. S. M., Ajward, A. R. \& Haque, A. K. M. A. (2015). The effects of demographic factors on job satisfaction of University Faculty of members in SriLanka. International Journal of Academic Research and Reflection, 3, 89-106. 
Asan, J., \& Wirba, V. (2015). Academic Staff Job Satisfaction in Saudi Arabia: A Case Study of Academic Institutions in the Eastern Province of Saudi Arabia. Research on Humanities and Social Sciences, 7(2), 7389.

Blackwell, R. \& Bryson, C. (2006). Managing temporary workers in higher education: Still at the Margin? Personnel Review. Farnborough 35(2).

Bryson, C. and Barnes, N. (2000). The Casualisation of HE in the United Kingdom Academic Work and Life: What it is to be an Academic, and how this is changing, Edited by Tight, M. 187-241. Oxford: Elsevier Science.

Barlas, B.(2016). Job Satisfaction among Academic staff in a Faculty Reputable Turkish University: Past and Present. International Journal of Contemporary Educational Research. 3(1), 1-11.

Derakhshani, A., Ghasemzadeh, A., \& Branch, M. (2014). A Survey about the Correlation between Accountability Job Satisfaction, Job Performance, Job Tension and Organizational Citizenship Behavior ( OCB ) in Faculty Members of East Azerbaijan PNU, 3(11), 781-786.

Gurinder, K. \& Gursharan, S. K. (2010). Job satisfaction: a challenging area of research in Education.

Herberg, F., Mausner, B. (1959). The Motivation to Work. New York: Wiley.

Hesli, V. L., \& Lee, J. M. (2013). Job satisfaction in Academic Why are some Faculty members happier man other? Political Science \& Politics, 46(2) 339-354. Nattps://doi.org/10./017/S1049096513000048.Howell, S. L. \& Hoyt, J. (2007). Job satisfaction among Civilian staff in the Zimbabwe Republic Police. Academic Leadership: The online Journal 8(4).

James, C. M. (2011). Workplace Social Support and Personality Type as Predictors of Job Satisfaction. University of Nigeria.

Lincoln, J. R. \& Kalleberg, A. L. (1990). Culture, control and commitment: A study of work organization and work attitudes in the United States and Japan. Cambridge: Cambridge University Press.

Moloantoa, M. E. and Dorasamy, N. (2017). Job satisfaction among academic employees in institutions of higher learning. Problems and Perspectives in Management, 15(3), 193-200.

Malik, M. E., Danish, R. Q., \& Munir, Y. (2012). The Impact of Pay and Promotion on Job Satisfaction: Evidence from Higher Education Institutes of Pakistan. American Journal of Economics, (June), 6-9.Maslow \& Abraham, H. (1943). "A Theory of Human Motivation”. Psychological Review 50:370-396).

Nguni, S., Sleegers, P. \& Denessen, E. (2006). Transformational and transactional

leadership effects on teachers' job satisfaction, organizational commitment, and organizational citizenship behavior in primary schools: The Tanzanian case. School Effectiveness and School Improvement. An International Journal of Research, Policy and Practice, 17, 145-177.

Saba(2011). Job Satisfaction of the academic staff of the vocational school of the foundation and public Universities. Quality assurance in education. 22(2), 185-206

Santhapparaj, A. S., \& Alam, S. S. (2005). Job satisfaction among academic staff in private universities in Malaysia Journal of Social Sciences, 1(2), 72-76.

Ssesanga, K., \& Garrett, R. M. (2005). Job satisfaction of university academics: Perspectives from Uganda. Higher Education, 50(1), 33-56. https://doi.org/10.1007/s10734-004-6346-0

Veitch, J. A., Charles, K. E., Farley, K. M. J. And Newsham, G. R. (2007). A model of satisfaction with open plan office conditions: COPE field findings. Journal of Environmental Psychology, 27, 177-189. 